\title{
Model of disorientation and Disqualification of Peripheral Services in Public Services On Local Government Device Work Units In Central Java, Indonesia.
}

\author{
RIO DHANI LAKSANA, VIVIANA MAYASARI, REFIUS PRADIPTA SETYANTO \\ Department Management Faculty Economics and Business \\ Jenderal Soedirman University \\ H.R. Boenyamin 708 Street, Purwokerto \\ INDONESIA
}

\begin{abstract}
Improving the quality of public services is inherent in the implementation of the tasks and functions of the Regional Work Unit as an extension of the tasks of the central government. The public service unit becomes a service node for integrated service offices in the district while improving the quality of service to the community. This study aims to examine the relationship of power orientation behavior, the process of service improvement through Peripheral Disorientation and Discipline for Public Service providers in the Regional Work Unit in Central Java. This study used a sample population of 181 Regional Work Unit public service employees. This study uses an analysis technique that is Regression weight in SEM which is used to examine how much the relationship between the variables. The model for research is illustrated by a path diagram. This is to make it easier to see the causality relationship between the variables to be tested. Based on this research it can be concluded that: Power-motivated behavior has a positive influence on disorientation of public services. Power behavior has a positive influence on the disqualities of peripheral services. The behavior of public service discuality affects the discuality of Peripheral services. Peripheral service orientation is positively influential on the Performance of Public Service Providers. Peripheral service disorientation has a positive effect on the performance of public service providers so that public service provider agencies in this one-stop public service center in Banyumas district can control the power-motivated behavior carried out by the Banyumas Government Officer. If this can be carried out, then it is likely that public service providers will be able to reduce the disorientation of public services carried out by public service providers when serving the public. This finding contributes to research on power motivation in organizations conducted by Dolatabadi \& Safa (2010), Oloko and Ogutu (2012) and Feeney (2011).
\end{abstract}

Key-Words: - disorientation, peripheral discuality, public services, service standards, bureaucracy

Received: March 24, 2020. Revised: August 17, 2020, Re-revised: August 30. Accepted: September 8, 2020. Published: September 11, 2020.

\section{Introduction}

Shifting or changing the paradigm of government administration from Reinventing Government (bureaucratic Entrepreneurship), Good Governance, New Public Management, to New Public Service, is a shift in the identity of modern government to meet the demands the wants and needs of the public to be cheap, timely, satisfied and happy physically and spiritually. Minimum Service Standards (SPM) can be an instrument for state administrators to protect their citizens and communities wherever and whenever they are. Because by setting SPM, it can be used as an instrument to determine the standard time, cost and procedure as well as an instrument to measure and check the rights of citizens served, whether according to standards and procedures or not. For the government, with SPM can also be used as an instrument of coaching and supervision to the administrators at the lower level which is part of the performance measurement of its employees. Quality service is an important basic element for any institution, both commercial and public, to build good relationships with consumers and each organization must improve their competitiveness by providing better quality of service (Liu and Tsai, 2010). The quality of public service delivery in the regions must be improved. Changes or reforms in 
the administration of public services are directed at optimizing service delivery at the level of service closest to the community. With the issuance of Government Regulation Number 19 concerning Subdistricts, Law Number 25 of 2009 concerning Public Services and Law Number 23 of 2014 concerning Regional Government, the role of the sub-district as a Regional Work Unit that is administratively, geographically and philosophically close to the community, has an increasing role.

This research starts from the problem of differences in research regarding the influence of performance-oriented performance management services. In addition there is a phenomenon that occurs in the community that the regulation of public services carried out are scattered and many rules are sectoral so that public services in each region in Indonesia are not yet manageable. Based on the above, the following problem formulations can be made.

The formulation of the problem in this study are as follows:

1. Does power-oriented behavior affect the performance of public service providers?

2. Does the power-oriented behavior affect the discuality of peripheral services which will result in a decline in the performance of public service providers?

3. Does the power-oriented behavior affect the disorientation of public services which will result in a decline in the performance of public service providers?

\section{Method}

Qualitative analysis is done to see the general picture of demography by looking at the index number of answers and relationships between variables which are then connected with answers to open questions. Quantitative analysis is done by validity test, reliability test, normality test, and hypothesis test using IBM AMOS 21 program. This study uses an analysis technique that is Regression weight which is used to examine how much the relationship between the variables. The model for research is illustrated by a path diagram. This is to make it easier to see the causality relationship between the variables to be tested.

\section{Result And Discussion}

\subsection{Data Screening Process}

In total 200 questionnaires were distributed and 181 questionnaires were returned. A total of 181 questionnaires returned in accordance with the specified time, but there were 18 questionnaires that were not filled out completely, and as many as 1 questionnaire exceeded the specified time. Thus the questionnaire used in the analysis is a complete questionnaire filled in and in accordance with the specified time that is as many as 181 questionnaires.

Respondents in this study were 181 respondents Banyumas Public Service Mall government employees. The screening process for the questionnaire to arrive at a suitable questionnaire analyzed in this study is presented in table 3 .

Table 3 Data Screening Criteria

\begin{tabular}{|l|c|}
\hline & Banyumas Public Service Mall \\
\hline Questionnaire distributed & 200 \\
\hline Return Questionnaire & 181 \\
\hline $\begin{array}{l}\text { The questionnaire returned in accordance with the specified } \\
\text { time }\end{array}$ & 181 \\
\hline $\begin{array}{l}\text { Questionnaire Returns not in accordance with the determined } \\
\text { time }\end{array}$ & 0 \\
\hline Questionnaire Not Returned & 27 \\
\hline Response Rate & $87,1 \%$ \\
\hline $\begin{array}{l}\text { The questionnaire was incomplete to be filled out and did not fit } \\
\text { the sample criteria }\end{array}$ & 0 \\
\hline Eligible Questionnaire & 181 \\
\hline
\end{tabular}

Source : Data processed, the results of SPSS output 
Based on table 3 above, it shows that the response rate is $87.1 \%$. This implies that the responses of respondents to the questionnaire that has been distributed get a good response from the respondents.

\subsection{Descriptive Statistics}

Analysis of the description of respondents' answers to the questions contained in the research questionnaire about strategic performance measurement system variables, job relevant information, role ambiguity, role conflict, the number of role demands and managerial performance is presented in table 4 . Table 4 displays the number of respondents, the minimum value, the maximum value, the average value and the standard deviation of each research variable. The first descriptive analysis of the data, namely the Behavior patterned variable consists of 3 requirements with rating scores on a scale of 1 (very low) to 7 (very high), with a midpoint score 4 . Theoretical range is 9 to 63 , while based on the results the study obtained a range of scores with a minimum value of 13 and a maximum value of 63 . Based on the average total answers given by respondents, obtained results of 47.8 with a standard deviation of 8.6. these results indicate that respondents are average and respond towards positive answers and state that behavior patterned power affects the performance of public service providers. The second variable is Public Service Disorientation consisting of 4 questions with rating scores on a scale of 1 (very low) to 7 (very high), with a midpoint score 4 . Theoretical range is 3 to 21 , while based on the results of the study obtained range of scores with a minimum value of 7 and a maximum value of 21. Based on the average total answer given by the respondent, a result of 17.4 is obtained with a standard deviation of 2.6. this means that the average respondent answered and stated that Public Service Disorientation is very important for public services. The third variable is Table 4 Descriptive Statistics of Research Variables the distortion of public services consisting of 3 questions with rating scores on a scale of 1 (very low) to 7 (very high), with a midpoint score 4 . Theoretical range is 24 to 168 , while based on the results of the study obtained range of scores with the minimum value of 24 and the maximum value is 102 . Based on the average total answers given by respondents, the results obtained were 59.1 with a standard deviation of 16.6. this means that the average respondent answered and stated that the lack of clarity over the certainty of the objectives and tasks that must be carried out in his work unit, led to the ambiguity of the role in carrying out the task. The fourth variable consists of the Disquality of Public Service Peripherals consisting of 4 questions with an assessment score on a scale of 1 (very low) to 7 (very high), with a midpoint score 4 . Theoretical range is 11 to 77 , while based on the results of the study obtained range of scores with a minimum value of 11 and a maximum value of 77 . Based on the average total answer given by the respondent, a result of 31.2 is obtained with a standard deviation of 10.2. this means that the average respondent answers and states that managers who receive different information have the potential to experience role conflict in carrying out the task. The fifth variable is the Performance of Public Service Providers consisting of 4 questions with rating scores on a scale of 1 (very low) to 7 (very high), with a midpoint score 4 . Theoretical range is 9 to 63 , while based on the results of the study obtained range of scores with a minimum value of 13 and a maximum value of 63 . Based on the average total answers given by respondents, the results obtained were 49.6 with a standard deviation of 8.2. these results indicate that the average respondent answered and stated that he has good performance and has a good understanding of the work unit area that is under his authority.

\begin{tabular}{|l|c|c|c|c|c|c|}
\hline \multicolumn{1}{|c|}{ Variable } & $\mathrm{n}$ & $\begin{array}{c}\text { Theoretical } \\
\text { Range }\end{array}$ & $\begin{array}{c}\text { Empirical } \\
\text { Range }\end{array}$ & $\begin{array}{c}\text { Theoretical } \\
\text { Average }\end{array}$ & $\begin{array}{c}\text { Total } \\
\text { Average }\end{array}$ & $\begin{array}{c}\text { Total Standard } \\
\text { Deviation }\end{array}$ \\
\hline Power behavior & 181 & $9-63$ & $13-63$ & 36 & 47.8 & 8.6 \\
\hline $\begin{array}{l}\text { Public Services } \\
\text { Disorientation }\end{array}$ & 181 & $3-21$ & $7-21$ & 12 & 17.4 & 2.6 \\
\hline $\begin{array}{l}\text { Public Service } \\
\text { Distortion }\end{array}$ & 181 & $11-77$ & $11-77$ & 44 & 31.2 & 10.2 \\
\hline $\begin{array}{l}\text { Disquality of } \\
\text { Peripheral Public } \\
\text { Services }\end{array}$ & 181 & $15-105$ & $15-96$ & 60 & 46.1 & 14.5 \\
\hline $\begin{array}{l}\text { Public Service } \\
\text { Provider } \\
\text { Performance }\end{array}$ & 181 & $9-63$ & $9-63$ & 36 & 49.6 & 8.2 \\
\hline
\end{tabular}

Source : Data processed, the results of SPSS output 
Table 5 Structural Model Match Test Results

\begin{tabular}{|l|c|c|c|}
\hline \multicolumn{1}{|c|}{ Index Match } & Model Results & Recommended value & Model Evaluation \\
\hline Chi-Square & 295.03 & 532.0754 & Good \\
\hline P.Value & 1.00 & $\geq 0.05$ & Good \\
\hline RMSEA & 0.57 & $0.05<\mathrm{RMSEA} \leq 0.80$ & Good \\
\hline Normed Fit Index $($ NFI) & 0.88 & $\geq 0.9 ; 0.80 \leq \mathrm{NFI}<0.90$ & Marginal \\
\hline Non- Normed Fit Index $($ NNFI) & 0.90 & $\geq 0.9 ; 0.80 \leq \mathrm{NNFI}<0.90$ & Good \\
\hline Comparative Fit Index (CFI) & 0.91 & $\geq 0.9 ; 0.80 \leq \mathrm{CFI}<0.90$ & Good \\
\hline Incremental Fit Index $($ IFI) & 0.91 & $\geq 0.9 ; 0.80 \leq \mathrm{IFI}<0.90$ & Good \\
\hline Goodness of Fit Index $($ GFI) & 0.89 & $\geq 0.9 ; 0.80 \leq \mathrm{GFI}>0.90$ & Marginal \\
\hline
\end{tabular}

Source : Hengki Latan, 2012

\subsection{Model Match Test}

$\mathrm{H}_{0}: \Sigma=\Sigma(\Theta)$ Model match the data

$\mathrm{H}_{1}: \Sigma \neq \Sigma(\Theta)$ Model does not match data

The test statistic used to test the above hypothesis is the chi square test. Table 5 is the results of structural model compatibility test.

The calculation results provide a chi square value of 295.03 with a value of p.value $=1$, which shows the model is very compatible with the data. In addition, other statistics such as RMSEA of 0,57 also support the conclusion that the model fits the data. The results of the analysis of the match test in general showed the research model included in the category of good compatibility with the data.

The results of the analysis of the model fit test as shown in table 4 show that the chi square value of 295.03 with the value of p.value $=1$, which shows the model is very compatible with the data. In addition, other statistics such as RMSEA of 0,57, NNFI, CFI and IFI show that the values of these indices are good. Subsequent evaluation results namely standardized RMR, NFI, RFI and GFI show that the values of these indices are marginal or quite good, this is because the structure of the model being built is very complex, so that it becomes one of the difficulties in getting a satisfactory compatibility test. The results of the analysis of the match test in general showed the research model included in the category of good compatibility with the data.

\subsection{The Influence of Power Behavior Towards Disorientation of Public Services}

Research results using empirical data can prove that the first hypothesis regarding the effect of power-motivated behavior on disorientation of public services can be accepted and statistically proven in this study. Power-motivated behavior has a positive influence on disorientation of public services. This result is in accordance with a study conducted by Dolatabadi and Safa (2010) which states that the high motivation of power and the lack of clarity of roles lead to the disorientation of services. Oloko and Ogutu (2012) stated that if the distance of power is low then the motivation of power increases and the impact on the low orientation of the target must be served by public organizations.

\subsection{The Effect of Power-Motivated Behavior on The Disqualities Of Peripheral Service}

The results of research using empirical data can prove that the second hypothesis regarding the influence of power-motivated behavior on the discuality of peripheral services can be accepted and statistically proven in this study. So that the patterned behavior of power has a positive influence on the diskuality of peripheral services.

The results of this study are compatible with the study of Tost et al (2011) which states the importance of the size of authority to avoid the domination of power motives in leadership that impacts the implementation of servants. Brusse's research (2009) states that the motive for power in the process of providing services is still largely done which results in failure in public services.

\subsection{Influence The Influence of The Quality of Public Services on The Quality of Peripheral Services}

The results of research using empirical data can prove that the third hypothesis regarding the effect of public service discuality on Peripheral service discuality can be accepted and statistically proven in this study. So that the behavior of public service discuality affects the discuality of Peripheral services.

The results of this study are in accordance with a study conducted by Boyne (2008) which states that one of the problems in public management is the weak service orientation in public organizations. Dolatabadi and Safa (2010) research states that role ambiguity leads to ambiguity which causes unclear service orientation which results in service failure. 
Research Hoang et.al (2011) which concluded that the attitude of employees who are not oriented to customer service will affect the occurrence of service failures.

\subsection{Effect of Effect of Public Service Orientation on Performance of Public Service Providers}

The results of research using empirical data can prove that the fourth hypothesis regarding the effect of disorientation of public services on the performance of public service providers can be accepted and statistically proven in this study. So that public service disorientation has a positive effect on the performance of public service providers. The results of this study are not in accordance with the research of Jui Wu (2009) which states that there is a negative relationship between the incompatibility of understanding the service process with the performance of front liner employees. The study of Jain et al 2011 concludes that misunderstanding in the service process will impact on the performance of service providers.

This research results are different because the object of this study is a public company that does not have the purpose of seeking profits so that the disorientation of public services has a positive effect on the performance of public service providers. As a public service that is monopolistic and is always needed by the community even though they are not satisfied the community does not have any other choice to get the public service.

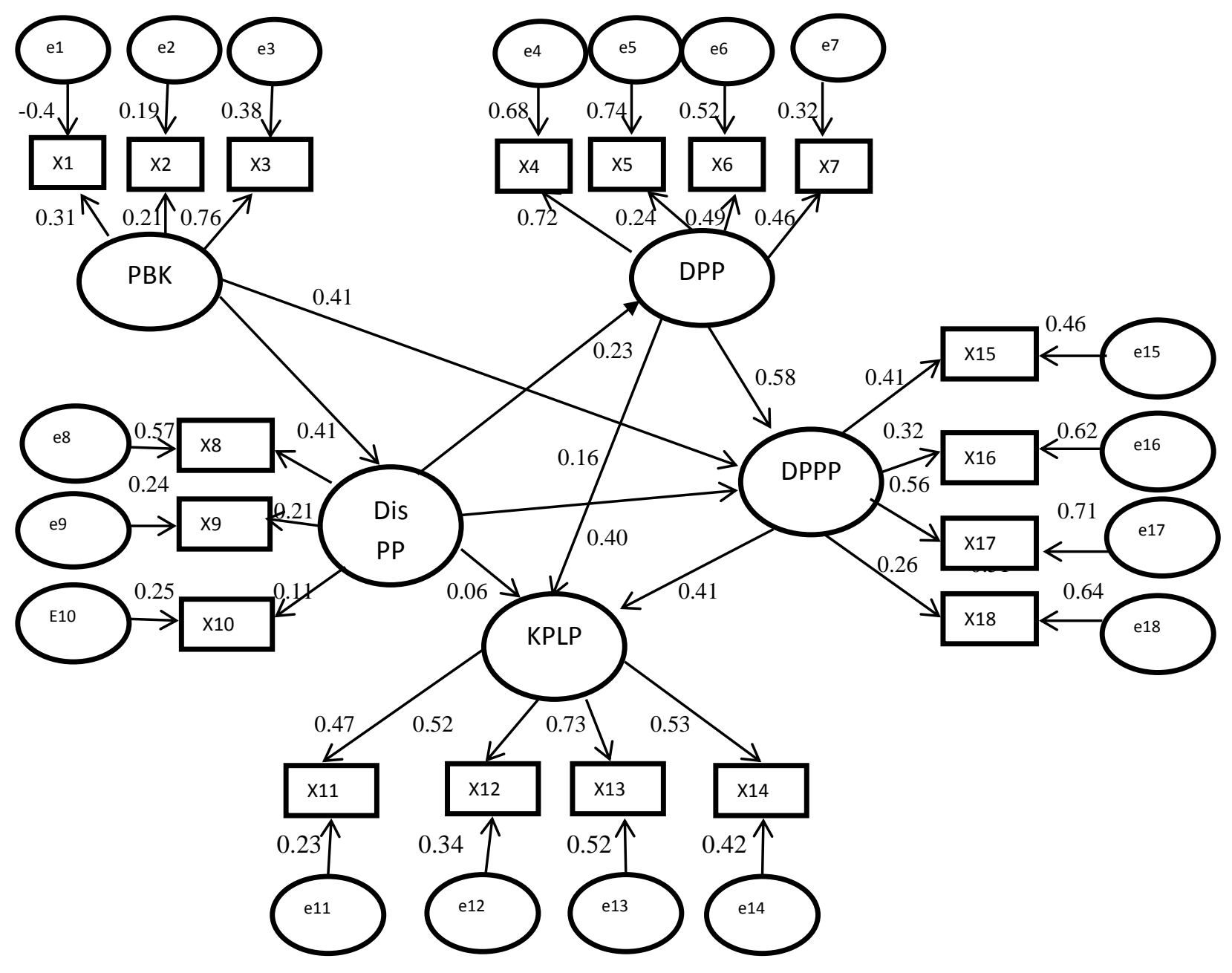

Figure 1 Results of Full Structural Equation Model 


\subsection{Effect of Influence on Peripheral Service Orientation on Public Service Provider Performance}

The results of the study using empirical data can prove that the fourth hypothesis regarding the influence of peripheral service disorientation on Public Service Provider Performance can be accepted and statistically proven in this study. So that the disorientation of peripheral services has a positive effect on the performance of public service providers.

The results of this study are in accordance with a study conducted by Byon \& Baker (2011) which states that employee behavior can be a cause of failure to manage peripheral services that will affect the performance of company services. Research Hume (2008) states that if there is no balance, the failure of peripheral services has a significant effect on service performance. Kaufmann et. al research (2015) states that poor behavior of public service providers will create service failures that will affect the performance of public services.

\section{Conclusion}

The research was made to conduct an in-depth study of how to build models to improve the performance of public service providers by reducing poweroriented behavior so as to reduce the disqualities of peripheral delivery so that the performance of service providers in relation to public services in Banyumas district can be improved.

Based on this research it can be concluded that Power-motivated behavior has a positive influence on disorientation of public services., Power-motivated behavior has a positive influence on the disqualities of peripheral services., The behavior of public service discuality affects peripheral service quality, Peripheral service disorientation has a positive effect on the performance of public service providers. Peripheral service disorientation has a positive effect on the performance of public service providers

So that the public service provider agencies in this One Door Public Service Center in Banyumas district can control the patterned behavior of power carried out by the Banyumas SKPD staff. If this can be carried out, then the possibility of public service providers will be able to reduce the disorientation of public services by the public service providers when serving the community. This finding contributes to the research, power activation in organizations carried out by Dolatabadi \& safa (2010), Oloko and Ogutu (2012) and Feeney (2011).
This research also pays attention to efforts to reduce the disqualities of peripheral services so that the performance of public service providers also increases.

Activities to reduce the disqualities of peripheral services include: Prioritizing trivial things that are not substantial like the ink color stamped must be blue, Excessive administrative requirements, for example: must be complete ID card and letter of introduction from the village and sub-district for the administration of population documents.3. Conduct discriminatory actions, for example, prioritizing those who are well known and those who are rich in the area.

\section{References:}

[1] Boshoff, C. (2007). "Understanding Service Recovery Satisfaction From a Service Encounter Perspective: Pilot Study," Journal of Business Management, Vol.38(2), pp. 41-51.

[2] Cho, Y. C. (2012). "The Effects of Customer Dissatisfaction on Switching Behavior in The Service Sector. Journal of Business \& Economics Research, Vol.10(10), 579-592.

[3] Cho, Y., Im I., Hilz, R., \& Fjermestad, J. (2002). The Effect of Post-Purchase Evaluation Factors on Online vs. Offline Customer Complaining Behavior: Implications for Customer Loyalty. Advance in Consumer Reasearch Journal, Vol.29, 318-327.

[4] Colgate, M., \& Norris, M. (2001). Developing a Comprehensive Picture of Failure. International Journal of Service Industry Management, 12(3), 215-233.

[5] Crie, D. (2003). Consumers' Complaint Behavior, Taxonomy, Typology and Determinants: Towards a Unified Ontology. Database Marketing \& Consumer Strategy Management, 11(1), 60-79.

[6] De Matos, C., Henrique, J. L., \& Ross, C. A. V. (2007). Service Recovery Paradox: A MetaAnalysis. Journal of Service Research, 10, 6077.

[7] Fernandes, D. V. H., \& Santos, C. P. (2007). Consumer Complaining Behavior in Developing Countries: The Case of Brazil. Journal of Consumer Satisfaction, Dissatisfaction and Complaining Behavior, 20, 86-109.

[8] Heung, V. C. S., \& Lam, T. (2003). Customer Complaint Behavior Towards Hotel Restaurant Services. International Journal of Contemporary Hospitality Management, 15(5).

[9] Holloway, B. B., \& Beatty, S. E. (2003). Service Failure in Online Retailing: A 
Recovery Opportunity. Journal of Service Research, 6, 92-105.

[10] Jang, Y. J., Cho, S. B., \& Kim, W. G. (2013). Effect of Restaurant Patrons Regret and Disappointment on Dissatisfaction and Behavioral Intention. Journal of Travel \& Tourism Marketing, 30(5), 431-444.

[11] Kau, A. K., \& Loh, E. W. Y. (2006). The Effect of Service Recovery on Consumer Satisfaction: A Comparison between Complainants and Non-Complainants. Journal of Service Marketing, 20(2), 101-111.

[12] Keaveney, S. M. (1995). Customer Switching Behavior In Service Industry: An Exploratory Study. Journal of Marketing, 59(2), 71-82.

[13] Kotler, P., \& Keller, K. L. (2012). Marketing Management (14e edition). Edinburgh Gate,
Harlow, Essex, England: Pearson Education Limited.

[14] Lee, R. \& Neale, L. (2012). Interactions and consequences of inertia and switching costs. Journal of Services Marketing, 26(5), 365-374.

[15] McCole, P. (2004). Dealing with Complaints in Services. International Journal o Contemporary Hospitality Management, 16(6), 345-354.

[16] Michel, S. (2004). Consequences of Perceived Acceptability of a Bank's Service Failure. Journal of Financial Services Marketing, 8(4), 367-377.

[17] Yi, Lee. J. (2015) An empirical study on the costumer respons to service recovery in the context of service failure. Seoul Journal of Business, Volume 11, 1-17.

\section{Creative Commons Attribution License 4.0} (Attribution 4.0 International, CC BY 4.0)

This article is published under the terms of the Creative Commons Attribution License 4.0

https://creativecommons.org/licenses/by/4.0/deed.en_US 